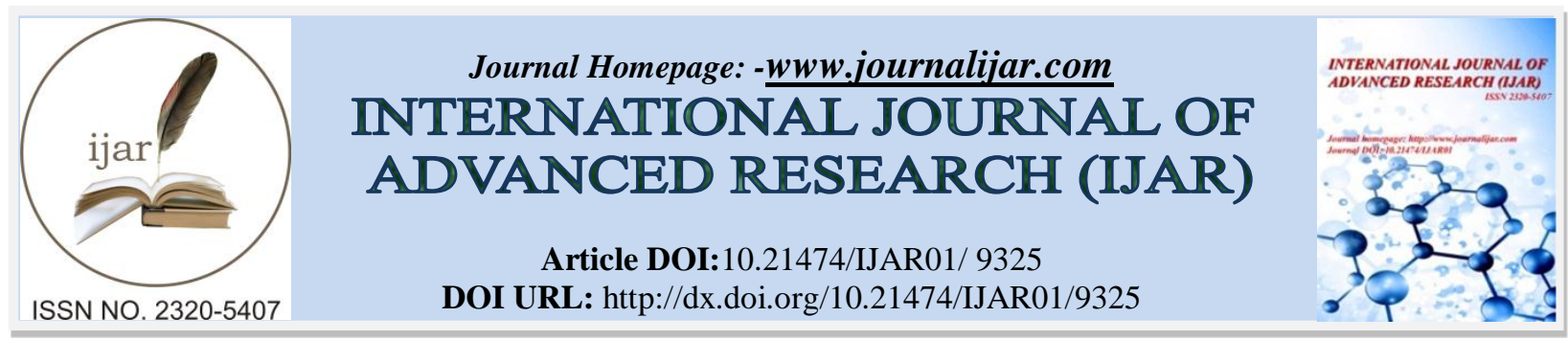

RESEARCH ARTICLE

\title{
INHIBITORY EFFECT OF ALPHA LACTALBUMIN AND CASIENGLYCOMACROPEPTIDE ON MUTANS STREPTOCOCCI COUNT IN DENTAL PLAQUE.
}

\section{Khaled Abd-Elmonem Sayed Masoud ${ }^{1}$,Dr. Mohamed Sherif Mohamed Salah Eldin Farg ${ }^{2}$, Dr. Osama Ibrahim Abd El-Salam El-Batawy ${ }^{3}$ and Dr. Shereef Samy Abd-El-Lateef ${ }^{4}$.}

1. Assistant Lecturer at Pediatric Dentistry Department, Faculty of Dentistry, Modern Sciences and Arts University (MSA), Egypt.

2. Professor of Pediatric and Preventive Dentistry and Dental Public Health, Faculty of Dentistry, Suez Canal University, Egypt.

3. Associate professor of Food Science and Technology, Faculty of Agriculture, Ain-Shams University, Egypt.

4. Lecturer of Pediatric and Preventive Dentistry and Dental Public Health, Faculty of Dentistry, Suez Canal University, Egypt.

\section{Manuscript Info}

Manuscript History

Received: 02 May 2019

Final Accepted: 04 June 2019

Published: July 2019

Key words:-

Plaque, Chlorhexidine, Milk whey,

Casein, Casienglycomacropeptide,

Alphalactalbumin.

\section{Abstract}

Milk or milk component-based drinks seem to possess many of the biological and physical properties desired for a saliva substitute. Milk contains two primary sources of protein, the caseins and whey. AlphaLactalbumin ( $\alpha$-LA) is one of the main proteins found in human and bovine milk whey. Glycomacropeptide is a major component of casein protein $\alpha$-La with antimicrobial properties have been reported as $\alpha$-La yielded bactericidal peptides. Both demonstrate a number of biological activities in medicine not only as milk protein but also as natural antibacterial.

Aim of the study: To examine the antibacterial activities of milk proteins glycomacropeptide and alpha lactalbumin compared with chlorhexidine and their effect on Mutans streptococci count in human dental plaque samples from children.

Materials and methods: Twenty children patient were sampled as follow six dental plaque samples were taken from each child from the buccal surface of first permanent molars, by sterile dental excavator and stored in Epindorff tube, then divided into six groups (Control group, Chlorhexidine group, Alpha lactalbumin $1 \%(\alpha \mathrm{LA} 1 \%)$, Alphalactalbumin $\%$ ( $\alpha$ LA2\%,Casienglycomacropeptide1\%(GMP1\%), Casienglycomacropeptide 2\% (GMP 2\%)) then Mutans Streptococci in the plaque samples of tested children were evaluated using selective media for mutans Streptococci.

Results: GMP 2\% was the highest reduction followed GMP 1\%, $\alpha \mathrm{LA}$ $2 \%$ and $\alpha \mathrm{LA} \quad 1 \%$.Conclusion: Alpha lactalbumin and Casienglycomacropeptide had antibacterial effect on Mutans Streptococci preset in dental plaque in children.

Copy Right, IJAR, 2019,. All rights reserved. 


\section{Introduction:-}

Dental caries remains a major public health issue worldwide with high prevalence and significant social impact. It results from a demineralization process in which acidogenic and acidophilic bacteria embedded in a mature, wellarranged biofilm degrade the tooth substance, ultimately leading to cavitation (Wolff et al., 2013). Caries is a multifactorial process that requires a shift in plaque ecology to favor acidogenic and aciduric microbial species that is usually driven by frequent consumption of simple carbohydrates and is modified by host factors such as saliva (Dashper, S. G et al., 2016).

Many bacteria have been described in association with the cariogenic process, especially large populations of acidogenic and aciduric bacteria, such as Mutans Streptococci, Streptococcus sobrinus, and Lactobacillus, which are capable of demineralizing enamel by producing an acidic environment (Featherstone, J. D, 2000).

Mutans Streptococci possess many virulent properties, which support their role in the caries process. They become pathological under conditions that lead to frequent and prolonged acidification of the dental plaque. Mutans Streptococci adapt to the low $\mathrm{pH}$ of this environment and thus, increase their rate of acid production and lower plaque $\mathrm{pH}$ resulting in a cariogenic plaque (Jeevarathan, J. 2000). Controlling the causative factors could be done first, through inhibiting Mutans Streptococci (Fejerskov, 2004).Fluoride treatment used worldwide has successfully limited caries progression, but was not sufficient to control this infectious disease even when used together with professional tooth cleaning and dietary counseling in populations exposed to cariogenic microbiota (Haugejorden and Birkeland, 2005)

Chemo-prophylactic agents that are used in dental caries prevention include classical antibiotics such as penicillin and vancomycin. Plant derived compounds such as sanguinaria extract, non-ionic agents such as triclosan (anionic agents such as sodium dodecyl sulphate (SDS), (Chen and Wang, 2010) and cationic agents such as chlorhexidine (Anderson, 2003).

Chlorhexidine is a potent, hydrophilic bisguanide antiseptic agent. It reduces plaque formation and selectively inhibits the growth of Gram-positive cariogenic microorganisms including S. Mutans and some species of Lactobacillus. It binds to negatively charged particles including bacterial cell walls (Evans, 2015).

However, antibacterial agents delivered as mouthwashes, contain significant quantities of alcohol that may be accidentally swallowed particularly by young children; also they produce deleterious effects such as hypoglycemia, seizures, and death in children. Alcohol toxicity from this source has been reported (Kolikonda et al., 2014; Sperry and Pfalzgraf, 1990).

Due to the increase of antibiotic resistance and side effects of some antimicrobials on one hand, and the safety, availability, and relatively low costs of natural products on the other hand, a variety of natural products have been assessed for caries prevention as well as incorporated into dental products (Wassel and Khattab, 2017).

Natural products are major sources of bioactive molecules and pharmaceutical leads, and have therefore contributed significantly to drug development (Mishra and Tiwari VK, 2011).

Milk is an excellent protein food that provides essential amino acids and organic nitrogen for humans and animals of all ages. Milk also contains factors that have anti-cariogenic properties: calcium, phosphate, casein, and lipids Dairy products were recognized in the late 1950s as a food group that is effective in preventing dental caries (AIMUTIS, 2004).

Also, using peptides, these are formed by proteolytic cleavage from larger precursor proteins found in milk, prevent the colonization of Mutans streptococci at young ages may enhance caries resistance as the child grows older. In addition to Lactobacilli- presence in milk are proven to reduce the number of Mutans streptococci in saliva (Johansson, 2002). Milk contains two primary sources of protein, the caseins and whey (Walzem et al., 2002).

Whey protein is made up of $\beta$-lactoglobulin (50\%), $\alpha$-lactalbumin (20-25\%), bovine serum albumin (10-15\%), immunoglobulins $(10-15 \%)$, lactoferrin $(0.35-2 \%)$ and lactoperoxidase $(0.25-0.5 \%)$. Also, casein contains glycomacropeptide (GMP) at concentrations of up to $15 \%$ (Halpin et al., 2011).

Whey proteins, one of the two milk protein groups along with the caseins, have been found to be valuable dietary supplement and a functional food enhancer. Furthermore, whey proteins have been evaluated and recognized for their antimicrobial, antiviral and anti-carcinogenic effects (Sullivan et al., 2014). 
$\alpha$-Lactalbumin is the second most abundant protein in bovine-derived whey protein concentrates and whey protein isolates. It is available commercially as $\alpha$-lactalbumin- enriched whey protein concentrates obtained by filtration methods (Permyakov and Berliner, 2000).

High-purity $\alpha$-lactalbumin allows researchers to further evaluate the nutritional value of $\alpha$-lactalbumin as well as its unique amino acid profile and bioactive peptides. (Donald et al., 2018).

Glycomacropeptide (GMP), a sialic acid rich peptide, is formed by the cleavage of $\kappa$-CN between Phe105-Met106 by the action of rennet (chymosin) during the manufacture of cheese (Marshall, 1991).

Prevention of dental caries by milk-derived bioactive peptidesis a complex physical and chemical sequence of cascading events. In general, bioactive peptides with anti-cariogenic activity have multiple functions to prevent dental lesions including bacterial inhibition (Reynolds, 1995).

Dairy products were recognized as a food group that is effective in preventing dental caries (Anderson et al., 2004). The aim of the present study was to compare the antibacterial activities of milk proteins glycomacropeptide and alpha lactalbumin compared with chlorhexidine and their effect on Mutans streptococci count in human dental plaque samples.

\section{Materials and methods:-}

The experimental protocol of the present study follow the recommendations and got the approval of the Ethics Committee Faculty of Dentistry, Suez Canal University.

The materials used in this study are shown in the following tables;

Table 1:-

\begin{tabular}{|c|c|}
\hline Name & Source \\
\hline $\begin{array}{l}\text { 1. Alpha lactalbumin and } \\
\text { Casein- } \\
\text { glycomacropeptide }\end{array}$ & $\begin{array}{l}\text { - "The raw materials of Alpha lactalbumin ( } \alpha \text {-LA) and Casein- } \\
\text { glycomacropeptide (CGMP) used in this study were obtained from Arla } \\
\text { Foods Ingredients (Amba-Nr- Vivm- DK- } 6920 \text { Videbaek- Denmark)" } \\
\text { Preparation of tested solutions:"At the laboratory of Department of Food } \\
\text { Science and Technology, Faculty of Agriculture, Ain-Shams University the } \\
\text { preparation of inhibitory solutions of Alpha lactalbumin }(\alpha \mathrm{LA}) \text { and } \\
\text { Glycomacropeptide(GMP) were take place by suspended of } 1 \text { and } 2 \text { grams } \\
\text { of } \alpha \text { LA and GMP in } 100 \mathrm{ml} \text { sterilized distilled water then the four solutions } \\
\left(1 \%, 2 \% \text { of } \alpha \text { LA and } 1 \%, 2 \% \text { of GMP) were sterilized in autoclave at } 121{ }^{\circ} \mathrm{C}\right. \\
\text { for } 15-20 \text { minutes, after sterilization the different solution were stored at } 4{ }^{\circ} \mathrm{C} \\
\text { until use. }\end{array}$ \\
\hline 2. Chlorhexidine & $\begin{array}{l}\text { - "Chlorhexidine (HCL) } 0.125 \% \text { (Arab Drug Company for pharmaceutical } \\
\text { and chemical industries, Cairo- Egypt) was pursued from local Egyptian } \\
\text { market." }\end{array}$ \\
\hline $\begin{array}{l}\text { 3. Gram Staining, catalase } \\
\text { and oxidase test }\end{array}$ & $\begin{array}{l}\text { - Gram staining test reagents (Merck, Darmstadt, Germany). } \\
\text { - Catalase reagent; } \mathrm{H} 2 \mathrm{O} 2 \text { was obtained from (Arabic Laboratory Equipment } \\
\text { Company, Abbaseya, Cairo) } \\
\text { - Oxidase test strips (Microbiology Bactedent Oxidase, Merck, Darmstadt, } \\
\text { Germany) were used in this study. }\end{array}$ \\
\hline
\end{tabular}

\section{Culture Media:}

Mitis Salivarius Agar Base media supplemented with 1\% Potassium Tellurite solution modified by adding 0.2 units/ml Bacitracin and by increasing the sucrose concentration to 20\% (MSB) (Gold et al., 1973) was used to recover Streptococcus mutans from plaque samples. (Table 2) All media were prepared according to manufacturer Instructions. 
Table 2:-

\begin{tabular}{|c|c|c|}
\hline Name & Brand and source & Ingredients \\
\hline Mitis Salivarius Agar Base & HimediaLaboratories, PVT.LTD, India. & $\begin{array}{ll}\text { - } & \text { Pancreatic digest of casein. } \\
\text { - } & \text { Protease peptone. } \\
\text { - } & \text { NO.3, dextrose. } \\
\text { - } & \text { Saccharose. } \\
\text { - } & \text { Dipotassium phosphate. } \\
\text { - } & \text { Trypan blue. } \\
\text { - } & \text { Crystal violet. } \\
\text { - } & \text { Agar. }\end{array}$ \\
\hline Bacitracin discs & $\begin{array}{l}\text { HimediaLaboratories, PVT. } \\
\text { LTD, India. }\end{array}$ & $\begin{array}{l}\text { The disc contains } 10 \mathrm{IU} \\
\text { Bacitracin. }\end{array}$ \\
\hline Potassium Tellurite $1 \%$ & HimediaLaboratories, PVT.LTD, India. & $\begin{array}{l}1 \% \text { solution of Potassium } \\
\text { Tellurite. }\end{array}$ \\
\hline Sucrose $\left(\mathrm{C}_{12} \mathrm{H}_{22} \mathrm{O}_{11}\right)$ & $\begin{array}{l}\text { Hemajet, Islamic International } \\
\text { Establishment for Chemical and Lab } \\
\text { Materials, Egypt }\end{array}$ & $\mathrm{C}_{12} \mathrm{H}_{22} \mathrm{O}_{11}$ \\
\hline
\end{tabular}

Table 3:-showing the equipment and devices used in this study

\begin{tabular}{|c|c|}
\hline Name & Source \\
\hline 1) Sterile Epindorff & $\begin{array}{l}\text { Sterile containers, obtained from local Egyptian market, were used to collect plaque } \\
\text { samples }\end{array}$ \\
\hline 2) Incubation tool & $\begin{array}{l}\text { - Electric incubator (Ehret, Dipl. Ingw.Ehret GmbH, Germany). Anaerobic jar } \\
\text { (Oxide, Unipath Ltd, Hampshire, England). } \\
\text { - Gas Generating kit (Oxide, Unipath Ltd, Hampshire, England) to generate CO2 } \\
\text { and hydrogen i.e. anaerobic system generation. }\end{array}$ \\
\hline 3) Stereomicroscope & Stereomicroscope (Lux, Germany) was used to examine plaque samples. \\
\hline 4) Laboratory tools: & $\begin{array}{l}\text { Inoculation needles, glass slides, test tube nozzles, flask nozzles, glass pipette } \\
\text { nozzles, petri dishes, pipettes and other glasses, icebox, sterile saline solution. }\end{array}$ \\
\hline 5) Clinical materials & $\begin{array}{l}\text { Sterile dental excavator (DENTSPLY MAILLEFER Instruments Holding Sarl, } \\
\text { Chemin du Verger } 3 \text { CH-1338 Ballaigues - Switzerland). }\end{array}$ \\
\hline
\end{tabular}

\section{Experimental steps:}

\section{Case selection}

Twenty children patient attending the outpatient's clinic, Pedodontics department, Faculty of Dentistry, Suez Canal University, Ismailia, Egypt. An informed written consent was obtained from the patient parents prior to sampling and after insuring the patient suit with:

\section{Inclusion criteria}

1. Healthy children aged 7-9 years old.

2. Free of any systemic diseases.

3. No history of antibiotic treatment for the past two months.

4. Apparently good oral hygiene

5. Fully erupted first permanent molars

\section{Exclusion criteria}

1. First permanent molar missing.

2. Caries on the buccal surface of first permanent molar.

3. Periodontally healthy having probing depth more than $3 \mathrm{~mm}$ on clinical examination.

2. The inhibitory effect of $\alpha$-LA and GMP

The materials were added to 20 plaque samples of each group in the Epindorff tubes as follow; control, chlorhexidine and 4 treatment $(\mathrm{T})$ groups 


\section{Control group:}

Containing the original plaque samples without any treatment.

\section{Chlorhexidine group:}

The plaque sample was mixed with Chlorhexidine HCL $0.125 \%(1.25 \mathrm{mg} / \mathrm{ml})$ (positive control)

\section{Alpha lactalbumin1 \% group (T1):}

The plaque sample was mixed with Alpha lactalbumin $1 \%(10 \mathrm{mg} / \mathrm{ml})$

Alpha lactalbumin $2 \%$ group (T2) \%:

The plaque sample was mixed with Alpha lactalbumin $2 \%(20 \mathrm{mg} / \mathrm{ml})$

Casienglycomacropeptide1\% group $\left(\mathrm{T}_{3}\right)$ :

The plaque sample was mixed with casein glycomacropeptide $1 \%(10 \mathrm{mg} / \mathrm{ml})$

Casienglycomacropeptide $2 \%$ group $\left(\mathrm{T}_{4}\right)$ :

The plaque sample was mixed with casein glycomacropeptide $2 \%(20 \mathrm{mg} / \mathrm{ml})$

Then all Epindorff tubes were incubated at $37 \mathrm{C}^{\circ}$ for 1 hour to be disperse for 30 seconds by vortex mix, then tenfold dilutions were made by normal saline to have a full colony counting for the caries related microorganisms.

\section{Microbial analysis}

Mutans Streptococci in the plaque samples of tested children were evaluated using selective media for mutans Streptococci (Mitis Salivarius agar) (Duchin and Van Houte, 1978).

\section{a) Preparation of Selective Media}

1. Mitis Salivarius Bacitracin agar medium was prepared according to manufacturer instructions by suspending $90 \mathrm{gm}$ of the Mitis Salivarius agar powder in $1 \mathrm{~L}$ of distilled water and were mixed thoroughly.

2. The mix was heated with frequent agitation and boiled for 1 minute to completely dissolve the powder then autoclaved at $121^{\circ} \mathrm{C}$ for 15 minutes. The flask containing the mix was allowed to cool to $50-55^{\circ} \mathrm{C}$.

3. Bacitracin solution was prepared by dissolving 40 discs bacitracin in $20 \mathrm{~mL}$ distilled water.

4. The bacitracin solution and $1 \mathrm{ml}$ of $1 \%$ potassium tellurite solution were added to the medium and then properly mixed.

5. Then complete medium was not heated. $20 \mathrm{ml}$ of the prepared medium was poured in a sterile Petri dish. The Petri dishes were allowed to solidify at room temperature then they were stored in the refrigerator at $4^{\circ} \mathrm{C}$ until use (Riad, 2009).

\section{b) Culturing and incubation procedures:}

Using the semi quantitative culture method, collected samples were emulsified in a sterile tube containing $1 \mathrm{ml}$ of sterile nutrient broth. Then, serial dilutions (10 folds) were made for each sample.

Surface viable counts were done from each dilution on Mitis Salivarius Bacitracin agar plates, and then the plates were incubated anaerobically at $37^{\circ} \mathrm{C}$ and $5 \% \mathrm{CO} 2$ for 48 hours in the incubator (Isenberg, 2004).

\section{c) Counting procedure of Mutans Streptococci:}

1. All colonies with morphological characteristics for Mutans Streptococci were counted using colony counter.

2. Colonies of Mutans Streptococci should be appeared dark blue, small, raised, with irregularly margins and adherent. (Hamada and Slade, 1980)

3. The results were recorded in charts. Furthermore, the colonies were differentiated by Gram staining method. The countable plates were divided into 4 quadrants; the count of colonies was performed by using the counting technique in each quadrant separately then summation of the number of colonies in the 4 quadrants.

4. The results were expressed as $(\mathrm{CFU} / \mathrm{ml})$. The number of colonies per milliliter $(\mathrm{CFU} / \mathrm{ml}$ was determined by the following equation: Number of colonies $/ \mathrm{ml}(\mathrm{CFU} / \mathrm{ml})$ equal number of colonies counted $\times$ inverse of dilution $\times$ inverse the cultured volume (ml). 
d) Gram staining, catalase and oxidase tests:

Gram satins were applied to heat fixed microbial smear on microscopic slide and microscopically examined. Microbial culture was smeared to microscope slide and a drop of 3\% hydrogen peroxide was applied to determine catalase activity. Microbial culture was smeared and applied to oxidase test strip. Isolates were cocci shaped, Gram positive, catalase and oxidase negative.

\section{Statistical Analysis:-}

Data were presented as means and standard deviation (SD) values. One Way-ANOVA test to compare between different tested groups

Statistical analysis was performed using IBM (IBM Corporation, NY, and USA) and SPSS (SPSS, Inc., an IBM Company).

$\mathrm{P}<0.05$ was considered statistically significant $(\mathrm{S}), \mathrm{p}<0.001$ was considered highly statistically significant (HS), and $\mathrm{p} \geq 0.05$ was considered statistically non-Significant (NS).

The present study aimed to detect the effect of a functional dairy product which are alpha lactalbumin $(\alpha \mathrm{LA})$ and casein glycomacropeptide (GMP) on Mutans streptococci count in dental plaque.

\section{Results:-}

Table 4:-showing Mean and SD values of plaque Mutans Streptococci count at the baseline and after adding interventions

\begin{tabular}{|c|c|c|c|}
\hline Groups & Mean and SD values & \multirow{2}{*}{ P value } \\
\cline { 2 - 4 } & Baseline & After & $0.005^{* *}$ \\
\hline Chlorhexidine & $249350 \pm 252217$ & $63.70 \pm 27.23$ & $0.001^{* *}$ \\
\hline $\mathrm{T}_{1}$ (alpha lactalbumin) $1 \%$ & $249350 \pm 252217$ & $3895 \pm 7001$ & $0.003^{* *}$ \\
\hline $\mathrm{T}_{2}$ (alpha lactalbumin $2 \%$ & $249350 \pm 252217$ & $3956 \pm 3471$ & $0.006^{* *}$ \\
\hline $\mathrm{T}_{3}$ (glycomacropeptide) $1 \%$ & $249350 \pm 252217$ & $4549 \pm 3818$ & $0.002^{* *}$ \\
\hline $\mathrm{T}_{4}($ glycomacropeptide) $2 \%$ & $249350 \pm 252217$ & $1342 \pm 756$ & 0 \\
\hline
\end{tabular}

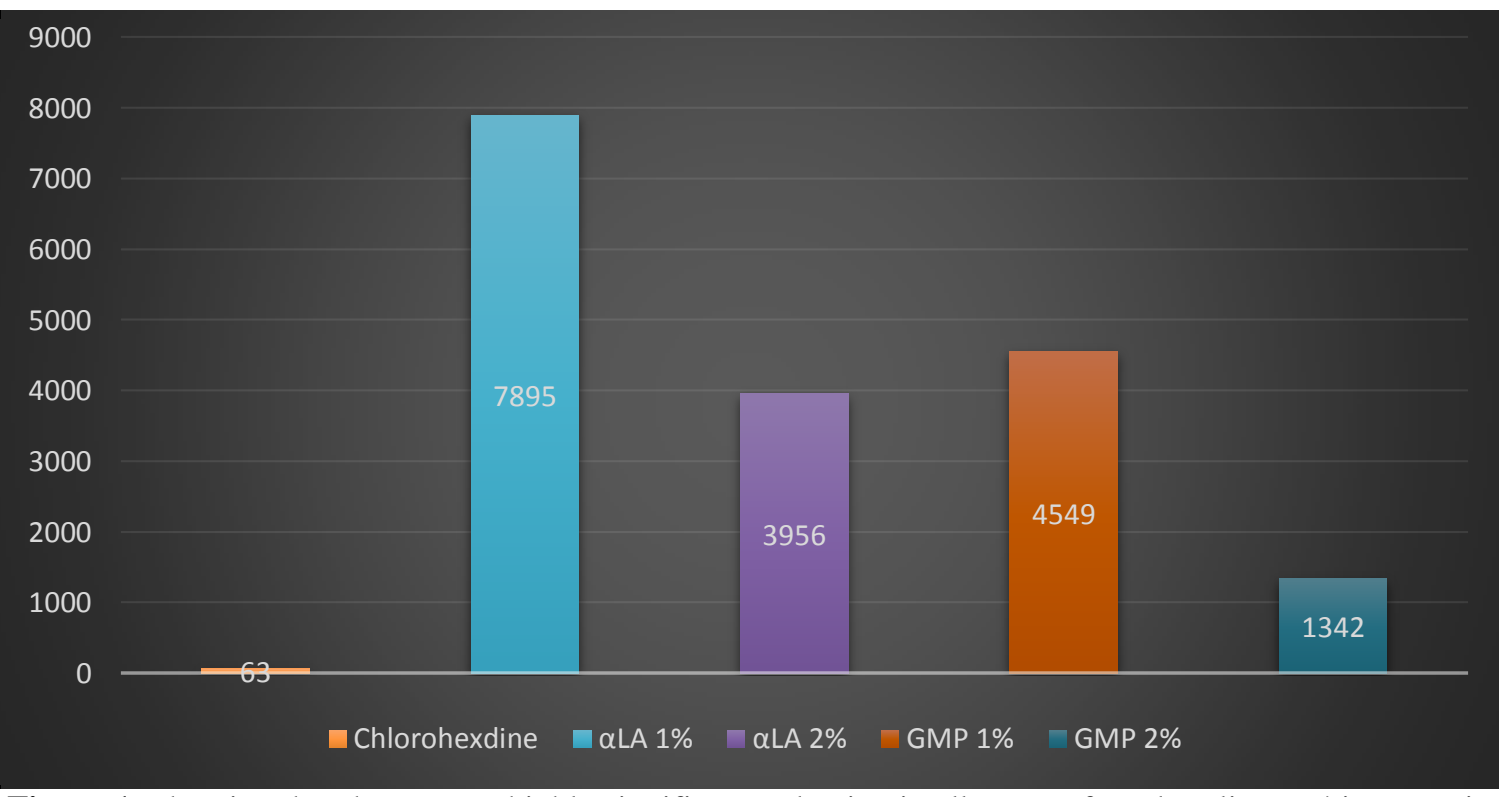

Figure 1:-showing that there was a highly significant reduction in all groups from baseline to 4 interventions where the $\mathrm{CHO}$ was the highest reduction followed by GMP $2 \%$ then GMP $1 \%, \alpha \mathrm{LA} 2 \%$ and $\alpha \mathrm{LA} 1 \%$. 


\section{Discussion:-}

As dental professionals it is our responsibility to reduce the incidence of dental caries by emphasizing the role of natural antibacterial in caries reduction. It is important that the dentist must be familiarized with alternatives to ordinary antibacterial. This initiated us to carry out this study.

Streptococcus mutans is the primary causal agent for dental caries especially in the initiation and development stages, ( Sperry and Pfalzgraf ,1990) and this microbe was first described in 1924 (Moynihan,2005).

Dental biofilm is a polymicrobial heterogenic community which provides several advantages to the microorganism to thrive with help of metabolic and phenotypic flexibility (Berezow and Darveau, 2011).Certain bacteria undergo genetic transformation by acquiring select genes in their genomes which render them as new phenotype in the biofilm community (Tribble et al. ,2013) In such situations, in vitro testing of antimicrobial using standard strains may not suffice and cannot be extrapolated to in vivo conditions. Considering this, we employed ex vivo antimicrobial testing of dental plaque samples from an oral cavity of children similar to the previous studies (Manipal et al., 2016).

The present study was conducted to evaluate and compare the antibacterial effect of two different milk proteins (Alpha lactalbumin ( $\alpha$-LA) and Casien glycomacropeptide (GMP)) on Mutans streptococci count in dental plaque in seven to nine years old children.

GMP was used in this study as one of the patented natural antibacterial agents against Mutans streptococci (Neeser, 1991). GMP has emerged as a multifunctional compound of particular interest in food science and nutrition for the manufacture of novel functional foods due to several biological activities, such as antibacterial and anti-cariogenic effect (Thomä-Worringer et al., 2006).

$\alpha$-LA was used in the present study as a well-known bactericidal peptides against Gram-positive bacteria. Unlike many other bactericidal peptides, the $\alpha$-LA-derived bactericides were anionic with the theoretical pIs of LDT1, LDT2 and LDC being 6.1, 4.5, and 5.3, respectively. (Pellegrini, 2003)

Chlorhexidine (CHX) is an antimicrobial agent that is particularly effective in reducing the levels of Mutans streptococci in saliva and dental plaque (Schaeken et al., 1989). Its effectiveness is attributed to its substantivity (i.e. its ability to maintain therapeutic activity for a prolonged period of time) which is facilitated by its adsorption onto tooth surfaces, pellicle, plaque and mucous membranes (Rölla et al., 1971).

CHX has been studied extensively both as an antiplaque and antigingivitis agent and for its potential to prevent and control dental caries (i.e. mouth rinse, gel, varnish, toothpaste) and concentrations (Balanyk and Sandham, 1985).

CHX is a positive effective agent against S. mutans. As per Pathan et al (2017), Chlorhexidine (HCL) was taken in present study, as a control group.

Several materials without the similar negative effects as CHX have been tried for long-term therapy, but none has been successful in providing similar anti-plaque and anti-gingivitis effect as the latter one. In recent time, Natural milk proteins have gained attention for their antibacterial properties, but none has been able to match that of CHX. (Hvas, 2016).

Milk possess a high beneficial effect, as milk is known by its anti-cariogenic and antibacterial property caused by its many components (Aimutis et al.,2004 ) that's why we had chosen milk proteins in the present study to evaluate their antibacterial effect.

Mutans Streptococci has been chosen in the present study because it is considered one of the most abundant microorganisms in the oral cavity responsible for caries development Kawashima et al., (2003) Mutans Streptococci used in this study, was isolated from Egyptian Pediatric patients attending the outpatient clinic in Pediatric Dentistry Department (Osman et al., 2013)

Mitis Salivarius Bacitracin Agar (MSB) containing sucrose and bacitracin was used for purification and quantification of Mutans Streptococci in accordance with Gold et al., (1973) who stated that the presence of sucrose and bacitracin in the Mitis Salivarius Bacitracin Agar at critical concentrations which are tolerated by Mutans Streptococci but not by other oral viridians streptococci make it a selective media for Mutans Streptococci isolation. 
This study was conducted on 20 patients from the outpatient's clinic, Pedodontics department, Faculty of Dentistry, Suez Canal University, Ismailia, Egypt. Total 120 samples were collected from the patients and divided into 6 groups equally.

The samples were collected from buccal surface of fully erupted $1^{\text {st }}$ permanent molar as it has large surface area and accessible. And from seven to nine years old children to make sure that the first permanent molar was fully erupted.

The most effective agents are those which exhibit a high degree of substantivity. To date, chlorhexidine is considered the most effective agent and is often used as the positive control by which to compare other agents (Neeser et al., 1988). In our study, S.mutans showed the highest sensitivity with CHX followed by GMP and finally $\alpha$-LA.

In this study CHX was found to reduce the S.mutans count by $60 \%$ and this agreed with Pathan et al., (2017) who conducted a study on the CHX as positive control and found CHX effective in reduction of S.mutans with 64\%

In the present study, GMP was found to reduce the Mutans Streptococci count by 30-40\%, this in accordance with Malkoski et al., (2001) who conducted a study on Casein glycomacropeptide and Antibacterial Peptide from Bovine Milk to see the inhibitory effect on Mutans Streptococci and they had found GMP reduced the S.Mutans count to $35 \%$.

In the present study, $\alpha$-LA. was found to reduce the Mutans Streptococci count by $20-30 \%$, this in accordance with Fijalkowski et al., (2012) who conducted a study on whey protein concentrate and its inhibitory Mutans Streptococci effect on and they had found $\alpha$-LA reduced the S.Mutans count to $22 \%$.

The results of the present study also revealed that the GMP show higher reduction than the $\alpha$-LA in the Mutans Streptococci count this result was in agreement with Fijałkowski et al., (2012) which found that GMP is more effective in inhibition of S.mutans than $\alpha$-LA.

The results also agreed with many studies which demonstrated that the incorporation of GMP and $\alpha$-LA as natural antibacterial (Neeser et al., 1988). In the same direction, Sah et al., (2018) and Aimutis et al., (2004) concluded that GMP and $\alpha$-LA were promising natural antibacterial that can compete the CHX.

Unlike Morrissey et al., (2012) who conducted a study on Inhibition of Streptococcus mutans using partially digested whey protein concentrate and individual whey proteins, they had found that GMP reduced the Mutans Streptococci count by $20 \%$ and this might be due to some additives to the GMP which restrict its action.

The disagreement with the present study was mainly due to the different protocol and material used in those studies in addition to the difference in source of S.mutans that was used in the present study from children.

\section{Conclusion:-}

\section{Based on the limitation of the present studies:}

1. The different concentrations of milk proteins $\alpha$-LA and GMP (1\% \&2\%) were found to be significantly less effective than Chlorhexidine (HCL) $0.125 \%$.

2. $\alpha$-LA (2\%) was significantly effective than $\alpha$-LA (1\%).

3. GMP $(2 \%)$ was significantly effective than GMP $(1 \%)$.

4. GMP (2\%) was nearly effective in S.Mutans count reduction as Chlorhexidine (HCL) $0.125 \%$.

5. Casein glycomacropeptide $2 \%$ was the strongest intervention in reducing the Mutans streptococci count.

6. Alpha lactalbumin 1\% was the weakest intervention in reducing the Mutans streptococci count.

\section{Acknowledgement:-}

1. I would like to gratefully acknowledge the support, supervision and kindness of Professor Dr. Mohamed Sherif

2. Special acknowledgement, gratitude and appreciation are due to Dr. Osama Ibrahim Abd El-Salam Elbatawy

3. I am greatly indebted to Dr. Shereef Samy Abd-El-Lateef 
4. Finally, endless thanks are extended to all my professors, colleagues, friends and staff members of the Pediatric Dentistry and Dental Public Health department, at MSA and Suez Canal University for their support and concern.

\section{References:-}

1. Aimutis, W. R., Anderson, G. H., \& Moore, S. E. (2004): The Emerging Role of Dairy Proteins and Bioactive Peptides in Nutrition and Health Dietary Proteins in the Regulation of Food Intake and Body Weight in Humans. Journal of Nutrition, 134(4): 974-979.

2. Aimutis, W. R. (2004): Bioactive properties of milk proteins with particular focus on anticariogenesis. J Nutr, 134: 989-995.

3. Anderson, G. H, Aimutis, W. R., \& Moore, S. E. (2004): The Emerging Role of Dairy Proteins and Bioactive Peptides in Nutrition and Health Dietary Proteins in the Regulation of Food Intake and Body Weight in Humans. Journal of Nutrition, 134(4): 974-979.

4. Anderson, M. H. (2003): A review of the efficacy of chlorhexidine on dental caries and the caries infection. J Calif Dent Assoc, 31: 211-4.

5. Balanyk, T.E. and Sandham, H.J. (1985): Development of sustained-release antimicrobial dental varnishes effective against Streptococcus mutans in vitro. J Dent Res ,64: 1356-1360

6. Berezow, A..B. and Darveau, R.P.(2011): Microbial shift and periodontitis. Periodontol, 55:36-47.

7. CHEN, F. and WANG, D. (2010): Novel technologies for the prevention and treatment of dental caries: a patent survey. Expert OpinTher Pat; 20: 681-94.

8. Dashper, S. G., Catmull, D. V., Liu, S. W., Myroforidis, H., Zalizniak, I., Palamara, J. E. A., Reynolds, E. C.( 2016): Casein phosphopeptide-amorphous calcium phosphate reduces streptococcus mutans biofilm development on glass ionomer cement and disrupts established biofilms. PLoS ONE, 11(9).

9. Donald, K L., Bo Lönnerdal, John, D. F. (2018):Applications for $\alpha$-lactalbumin in human nutrition, Nutrition Reviews, Volume 76(6) : 444-460.

10. Duchin, S. and Van Houte, J. (1978): Colonization of Teeth in Humans by Streptococcus mutans as Related to Its Concentration in Saliva and Host Age. Infect Immun, 20: 120-5.

11. Evans, A., Leishman, S. J., Walsh, L. U., \& Seow, W. K. (2015): Inhibitory effects of antiseptic mouthrinses on Streptococcus mutans, Streptococcus sanguinis and Lactobacillus acidophilus. Australian Dental Journal, 60(2): 247-254.

12. Featherstone, J. D. (2000): The science and practice of caries prevention. J Am Dent Assoc, 131:887-99.

13. Fejerskov, O. (2004): Changing paradigms in concepts on dental caries: consequences for oral health care. Caries Res, 38: 182-91.

14. Fijałkowski, K, Folan, M. A, Morrissey, P. E.W, Baird, A. W, \& Irwin, J.A. (2012): Inhibition of Streptococcus mutans binding to hydroxylapatite using partially digested whey protein concentrate and individual whey proteins. Journal of functional foods, 4: 559-567.

15. Gold, O. G., Jordan, H. V. \& Van Houte, J. (1973). A selective medium for Streptococcus mutans. Arch Oral Biol, 18, 1357-1364.

16. Halpin, R. M., Brady, D. B., O’Riordan, E. D., \& O’Sullivan, M. (2011): The effect of untreated and enzymetreated commercial dairy powders on the growth and adhesion of Streptococcus mutans. LWT - Food Science and Technology, 44(6):1525-1532.

17. Hamada, S., Slade, H.D. (1980): Biology, immunology, and cariogenicity of Streptococcus mutans. Microbiological Reviews. 44(2):331-384.

18. Haugejorden, O. and Birkeland, J. M. (2005): Analysis of the ups and downs of caries experience among Norwegian children aged five years between 1997 and 2003. ActaOdontolScand, 63:115-22.

19. Hvas, C. L., Dige, A., Bendix, M., Wernlund, P. G., Christensen, L. A., Dahlerup, J. F., \&Agnholt, J. (2016): Casein glycomacropeptide for active distal ulcerative colitis: A randomized pilot study. European Journal of Clinical Investigation, 46(6): 555-563.

20. Isenberg, H.D. (ed.). : (2004). Clinical microbiology procedures handbook, vol. 1, 2 and 3, 2nd ed. American Society for Microbiology, Washington, D.C.

21. Jeevarathan, J., Deepti, A., Muthu, M. S., Rathna Prabhu, V. \& Chamundeeswari, G. S. (2007): Effect of fluoride varnish on Streptococcus mutans counts in plaque of caries-free children using Dentocult SM strip mutans test: a randomized controlled triple blind study. J Indian SocPedodPrev Dent, 25: 157-63.

22. Johansson, I. (2002): Milk and dairy products: possible effects on dental health. Food \& Nutrition Research, 46: 119-122. 
23. Kawashima, M., Hanada, N., Hamada, T., Tagami, J. \& Senpuku, H. (2003):Real-time interaction of oral streptococci with human salivary components. Oral Microbiol Immunol, 18: 220-5.

24. Kolikonda, M. K., Sriramula, S., Joseph, N., Dannaram, S. \& Sharma, A. (2014): A Case of Mouthwash as a Source of Ethanol Poisoning: Is There a Need to Limit Alcohol Content of Mouthwash? Prim Care Companion CNS Disord , 16.

25. Malkoski, M., Dashper, S.G., O'Brien-Simpson, N.M. , Talbo, G.H., Macris, M. , Cross, K.J., Reynolds, E.C.( 2001) : Kappacin, a novel antibacterial peptide from bovine milk. Antimicrob Agents Chemother. 45(8):2309-15.

26. Manipal, S., Hussain, S., Wadgave, U., Duraiswamy, P., Ravi, K.( 2016): The Mouthwash War - Chlorhexidine vs. Herbal Mouth Rinses: A Meta-Analysis. Journal Of Clinical And Diagnostic Research. JCDR, 10 (5): 81-83.

27. Marshall, S.C. (1991): Casein macropeptide from whey. A new product opportunity. Food Res Quart ,51:86-91

28. Mishra, B.B., Tiwari, V.K. (2011): Natural products: an evolving role in future drug discovery. Eur J Med Chem., 46(10):4769- 4807.

29. Morrissey, P. E.W, Folan, M. A, Fijałkowski, K., Baird, A. W, \& Irwin, J. A. (2012): Inhibition of Streptococcus mutans binding to hydroxylapatite using partially digested whey protein concentrate and individual whey proteins. Journal of functional foods, 4:559-567.

30. Moynihan, P. J. (2005): The role of diet and nutrition in the etiology and prevention of oral diseases. Bulletin of the World Health Organization, 83: 694-699.

31. Neeser, J. R., Chambaz, A., Del Vedovo, S., Prigent, M. J., \& Guggenheim, B. (1988): Specific and nonspecific inhibition of adhesion of oral actinomyces and streptococci to erythrocytes and polystyrene by caseinoglycopeptide derivatives. Infection and Immunity, 56(12): 3201-3208.

32. Neeser, J. R. (1991): Dental anti-plaque and anti-caries agent. U.S. Patent, 4:992,420,241.

33. Osman, A., Abdalaziz, S., Mortada, A., Randa, Y., El-Batawy \& A., O. I.( 2013): Inhibitory Effect of Different Probiotic Bacterial Strains on Salivary Streptococcus mutans and Identification of the most Suitable Dairy Product for Delivery of the most Potent One: An In-vitro Study. Nature \& Science, 11: 188.

34. Pathan, M.M., Bhat, K.G., Joshi, V.M. (2017): Comparative evaluation of the efficacy of a herbal mouthwash and chlorhexidine mouthwash on select periodontal pathogens: An in vitro and ex vivo study. Journal of Indian Society of Periodontology, 21(4):270-275.

35. Pellegrini, A. (2003): Antimicrobial peptides from food proteins. Current pharmaceutical design, 9 (16): 12251238.

36. Permyakov, E.A. and Berliner, L.J. (2000): a-Lactalbumin: structure and function. FEBS Lett.,473:269-274.

37. Reynolds, E. C. (1995): Dairy products and dental health. Proc. Nutr. Soc. Aust. 19: 95-102.

38. Riad, H. R. M. (2009): In Vivo Effect of Two Products with Natural Ingredients on Caries Inhibition.

39. Rölla, G., Löe, H., Rindom, S. C. (1971): Retention of chlorhexidine in the human oral cavity. Arch Oral Biol, 16: 1109-1116.

40. Sah, B.N.P., Vasiljevic, T., McKechnie,S. \&Donkor, O.N.(2018): Antioxidative and antibacterial peptides derived from bovine milk proteins, Critical Reviews in Food Science and Nutrition, 58:5, 726-740.

41. Schaeken, M.J., Hoeven, J.S., Hendriks, J.C. (1989): Effects of varnishes containing chlorhexidine on the human dental plaque flora. J Dent Res, 68: 1786-1789.

42. Sperry, K. and Pfalzgraf, R. (1990): Fatal ethanol intoxication from household products not intended for ingestion. J Forensic Sci, 35: 1138-1142.

43. Sullivan S.T., Tang C., Kennedy A., Talwar S., Khan S.A, (2014): Electrospinning and heat treatment of whey protein nanofibers. Food Hydrocolloids. 35: 36.

44. Thomä-Worringer, C., Sørensen, J., LópezFandĩno, R. (2006): Health effects and technological features of caseinomacropeptide, Int. Dairy J.16: 1324.

45. Tribble, G.D., Kerr, J.E., Wang, B.Y. (2013): Genetic diversity in the oral pathogen porphyromonas gingivalis: Molecular mechanisms and biological consequences. Future Microbiol, 8:607-20.

46. Walzem, R.L., Dillard, C.J., German, J.B. (2002): Whey components: millennia of evolution create functionalities for mammalian nutrition: what we know and what we may be overlooking. Crit Rev Food SciNutr, 42:353-375.

47. Wassel, M. O., \& Khattab, M. A. (2017): Antibacterial activity against Streptococcus mutans and inhibition of bacterial induced enamel demineralization of propolis, miswak, and chitosan nanoparticles based dental varnishes. Journal of Advanced Research, 8(4): 387-392.

48. Wolff, D., Frese, C., Maier-Kraus, T., Krueger, T., Wolff, B. (2013): Bacterial biofilm composition in caries and caries-free subjects. Caries Res., 47(1):69-77. 